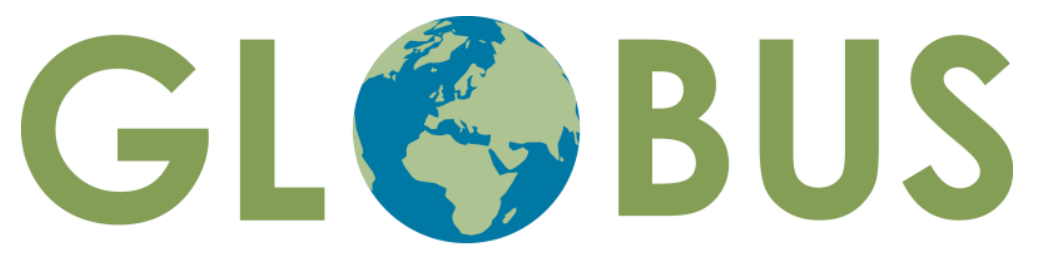

Reconsidering European Contributions to Global Justice

\title{
The Pursuit of Justice Through EU Security Strategies Sisyphus Redux?
}

Nikola Tomić and Ben Tonra

\section{GLOBUS Research Papers}

2/2018 - February 2018 
Nikola Tomić and Ben Tonra

The Pursuit of Justice Through EU Security Strategies: Sisyphus Redux?

GLOBUS Research Paper 2/2018

February 2018

(C) Nikola Tomić and Ben Tonra

GLOBUS Research Papers (online) | ISSN: 2535-2504

http: //www.globus.uio.no/publications/globus-research-papers/

Nikola Tomić is Postdoctoral Researcher at the School of Politics and International Relations, University College Dublin.

Ben Tonra is Jean Monnet Professor ad personam of European Foreign, Security and Defence Policy and Professor of International Relations at the School of Politics and International Relations, University College Dublin.

Reconsidering European Contributions to Global Justice (GLOBUS) is a research project that critically examines the EU's contribution to global justice.

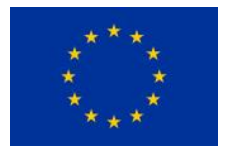

Funded by the European Union's Horizon 2020 programme. This work is the sole responsibility of the author. It does not reflect the opinion of the EU. The Research Executive Agency is not responsible for any use that may be made of the information it contains.

\section{www.globus.uio.no}

ᄂ Twitter:@globus_h2020

f Facebook:@globus.h2020

Issued by:

ARENA Centre for European Studies

University of Oslo

P.O. Box 1143 Blindern

0318 Oslo, Norway

www.arena.uio.no

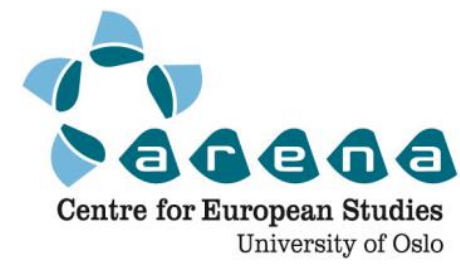




\section{Abstract}

The EU has developed its role in global affairs through several treaty revisions, institutional developments, political statements and official strategic documents. The strategic documents and political statements embody both the EU's more particular short-term interests and concerns, as well as its more universal and long-term normative aspirations or 'milieu goals'. How the EU has sought to balance these and to project them globally through its formal strategy statements in the realm of security is the core research question of this paper. Furthermore, this paper assesses these attempts as part of a greater endeavour of the GLOBUS project to conceptualise global justice and the Union's role therein. The EU is a (self-)proclaimed normative power that is seen in some quarters as promoting universal values and global justice. However, what is 'just', as this article will discuss, is contested even when it is (rarely) defined. The article will therefore review three related but distinct concepts of global justice and highlight the outlying indicators of these ideal types of justice. Based on these, the article develops hypotheses on the EU's role in the pursuit of global justice and tests these against the EU's discourses embodied in the three main strategic documents: 'A Secure Europe in a Better World - European Security Strategy' (European Council 2003), 'Report on the Implementation of the European Security Strategy - Providing Security in a Changing World' (European Council 2008) and 'Shared Vision, Common Action: A Stronger Europe - A Global Strategy for the European Union's Foreign And Security Policy' (EEAS 2016).

\section{Keywords}

European Union, global justice, European security strategy, global strategy

Research for this paper has received funding from the European Union's Horizon 2020 research and innovation programme under grant agreement no. 693609 (GLOBUS). 



\section{Introduction}

The European Union (EU) is a multifaceted global actor famously referred to as an economic giant, political dwarf and military worm by a former Belgian Foreign Minister, Mark Eyskens (Whitney 1991). Since then, the EU has moved on and has developed its role in global affairs through several treaty revisions, institutional developments, political statements and official strategic documents. The strategic documents and political statements embody both the EU's more particular short-term interests and concerns, as well as its more universal and long-term normative aspirations. How the EU has sought to balance these and to project them globally through its formal strategy statements in the realm of security is the core research question of this paper. Furthermore, the paper assesses these attempts as part of a greater endeavour to conceptualise global justice and the Union's role therein. The EU is a (self-) proclaimed normative power that is seen in some quarters as promoting universal values and global justice. However, what is 'just', as this article will discuss, is contested and often undefined. The article will therefore review three related but distinct concepts of global justice and, based on these, develop hypotheses on the EU's role in the pursuit of global justice and test these based on the EU's discourses surrounding the three main strategic documents: 'A Secure Europe in a Better World - European Security Strategy' (European Council 2003), 'Report on the Implementation of the European Security Strategy - Providing Security in a Changing World' (European Council 2008) and 'Shared Vision, Common Action: A Stronger Europe - A Global Strategy for the European Union’s Foreign And Security Policy’ (EEAS 2016).

\section{GLOBUS and the three understandings of justice}

What is 'just' in a global order and how to achieve it has been a contested topic (Rawls 1971; Walzer 1983; Barry 1989; Young 1990; Moellendorf 2002; Singer 2002; Buchanan 2004; Caney 2005; Nagel 2005; Fraser 2007; Lovett 2009; Sen 2009; Forst 2012, 2015; Dryzek 2013, 2015; Kolers 2014). Indeed, the very act of defining what is just, assumes a right and capacity to do so, and potentially sets up a position of domination vis á vis other actors and interests with the danger of itself creating another injustice. To avoid this, this paper calls for a systematic and reflexive analysis of the debate in the literature on both global justice and the EU's foreign and security policy. This paper will employ Eriksen's three conceptions of global justice: justice as non-domination, justice as impartiality and justice as mutual recognition (Eriksen 2016). The following sections will explore Eriksen's conceptions of global justice and will then infer hypotheses on how the EU might be seen to act - or to define its ambitions/actions - within its own foreign and security policy. This will allow us then to consider in detail how justice is, or is not, reflected within the European Union's formal security strategy statements from 2003 onwards. 


\section{Justice as non-domination}

'The academic debate on justice has generally taken the state as the point of departure' (Eriksen 2016: 7), with the state being 'a centralised system which determines the rules and possesses a monopoly on the power of enforcement' (ibid: 6). The state establishes and ensures justice, and in a Hobbesian sense, justice is seen as the protection of the collective self-interest and enforcing the laws that make such 'mutual advantage' possible (Barry 1989; Gauthier 1986). Domination of one individual over another is considered unjust in this framework. Accordingly, and in line with Pettit's thinking, justice is understood as non-domination of an individual by others. Justice assumes that an individual would enjoy the 'social status' and 'being able to enjoy a sense of security' (Pettit 2010: 77). This understanding of personal security is one of status or 'standing' (Eriksen 2016), regardless of presence of any real threat. One should be non-dominated in principle. Because of this principle one assumes the state will assure that no individual will arbitrarily use force against the other, and one does not live in fear of being arbitrarily dominated by another individual.

At the global level, Pettit's understanding of non-domination goes beyond simple nonintervention and assumes that non-domination is a mutual agreement of equal standing between all actors. The 'standing', the rights and obligations of actors, regardless of the level of analysis (states, groups or individuals) in this model are still state-centred and statebased, and rely on membership of a state. The states' function is the protection of its citizens from dominance, which is why state sovereignty and Westphalian principles are the point of departure when assessing justice as non-domination (Eriksen 2016: 11). Freedom is thus understood as a freedom from a dominating other. In the absence of a global super-state, the equal standing is ensured by a commonly agreed set of institutions and rules embodied in the principles of the United Nations, primarily the principles of sovereignty, inviolability of borders and refraining from the use of force to settle disputes.

Such a static and universally self-interested view of justice would shape the EU security strategy predominantly to reflect the direct interest of the EU, and would have 'limited capacity to eliminate dominance globally' (Eriksen 2016: 12). Arguably, it may well leave the EU in the dominating position, if the EU fails to consider broader justice claims and/or to address historic injustices - most especially where these were created or exacerbated by European (in)action(s). To avoid this type of injustice, Eriksen proposes a more impartial view of justice (2016: 12).

\section{Justice as impartiality}

While non-domination requires equal standing among states, justice as impartiality expects equality in rights and freedoms. In essence, these two views of justice do not differ in terms of their regard of dominance in global affairs as a core injustice. The disagreement stems from their understanding of how dominance can be avoided. The 
former advocates for the protection of state sovereignty and protecting a state's citizens through maintaining an international system of states through responsible political action. The latter emphasizes the 'need for a law-based order beyond the state' (Eriksen 2016: 13). The justice as impartiality position shares the concern over the lack of an international super-state. Since no state is likely to be an unbiased and nondiscriminating arbitrator, 'justice should be the content of an agreement that would be reached by rational people under conditions that do not allow for bargaining power to be translated into advantage' (Barry 1989: 7, cited in Eriksen 2016: 13). As such, justice as impartiality is a clear step beyond state sovereignty in ensuring non-domination. Unlike the view where non-domination is abolished through equality of status in a system that allows for bargaining of common agreements, justice as impartiality emphasises the equal right of all to freedom. These rights 'trump not merely collective goals but also national sovereignty understood in a particular way' (Dworkin 2011: 333, cited in Eriksen 2016: 14).

Instead of relying on the principle of non-domination being universal to all states, 'justice as impartiality underscores the need for authoritative institutions that interpret and enforce valid norms' (Eriksen 2016: 15), and in the case of global politics, these are international organisations that create and enforce international law and norms. If one is to protect the equal right of freedom and avoid the injustice of dominance, international institutions are expected to remove (military) power and leverage from cooperation between actors. In this sense, justice as impartiality at a global level would be congruent with justice as non-domination and propound the principles of the United Nations as the basis for global justice, but would emphasise the universality of fundamental rights and freedoms and the responsibility to protect these universal rights and freedoms. Freedom in this sense is understood as a freedom of equality and the absence of dominance as a given universal right, not one protected by the state.

Moreover, justice as impartiality, as Eriksen puts it, is a 'context-transcending principle' (2016: 14) that trumps state sovereignty. As such, justice as impartiality overcomes the challenge of state-centrism in the age of globalisation where dominance and injustice transcends state borders and requires more than state action to overcome. A just and impartial global order ought thus to rely on multilateral organisations as the key platform to ensure and actively to protect universal rights. Human rights discourses and the importance of individuals take priority over national sovereignty. Critically, the use of power (both force and 'soft power') by states gathered within multilateral organisations is considered acceptable - even necessary - if it promotes and protects fundamental rights and human security. In practice, however, impartiality and universality pose its own difficulties of concrete, particular application in global affairs. Justice in this view has a 'relatively abstract and vague nature, which increases the risk of glossing over relevant distinctions and differences' (Eriksen 2016: 17). Furthermore, while justice as impartiality removes the danger of paternalism from states, it does not eradicate the potential of 'monological moralism and/or authoritarianism in the form of a world state' (Eriksen 2016: 17-8) or a dominant international institution, forcing a hegemonic human rights discourse as the only acceptable one. Universality and equality 
can represent just guiding principles in global politics, but the question of who defines what justice is demands an answer based in agency and a mutual recognition of what justice is and should be.

\section{Justice as mutual recognition}

Justice as impartiality delineates the limitations of justice as non-domination, but both views of justice operate under the assumptions that eradicating dominance will create equality among all people and universal justice. However, the 'requisite sameness, the substantial equality necessary for citizens to see themselves as members of a "community of obligations", is not in place' (Eriksen 2016: 18). For this reason, the view of justice as mutual recognition relies on and is governed by the assumption of difference. Accordingly, justice 'cannot be grounded in our common humanity or abstract principles of equal freedom' (ibid: 18). Freedom is here understood as a freedom to be different and to be recognised/accepted as such. The goal is not equality in terms of sameness and like-mindedness but in equal opportunity to be heard and equal right to be respected.

At the global level, the unanswered question of who determines what abstract terms like equality, freedom and justice are, plagues both justice as non-domination and justice as impartiality. Such construction of meaning relies on agents to frame, interpret and reproduce concepts into practice. Global justice as mutual recognition warns against structural forms of injustice that extend beyond the state or 'fly under the radar' as '[f]raming effects arising from the unconscious assumptions of well-intentioned people, cultural stereotypes, market mechanisms, and other processes of ordinary life' (Eriksen 2016: 19). To avoid unintended injustices and inequity, caused by even well-intended agents, the view of justice as mutual recognition maintains that agency over the definition of justice must be shared. As Eriksen explains, 'we cannot know what is just unless all affected are heard' (ibid 2016: 19).

With these issues in mind, justice as mutual recognition must not just assume that representation is enough for the constitution of justice, but must advocate for tangible developments in ideology, institutions and material capabilities, which would allow for real mutual recognition. In this light, dominant discourses are flexible, constantly contested and shaped by all participants in the discourse equally, in spite of the unequal standing in the global arena. States, supra- and sub-state actors have equal access to justice claims, which even at the global level focuses on individuals' physical and human security.

\section{So, which justice is most just?}

How does Eriksen's categorisation of justice into three distinct conceptualisations help in assessing the EU's contribution to global justice? The distinction is indispensable not just to illustrate the contested definition of justice, but also to develop a more systematic framework for analysis of the EU's security strategy. The purpose of this paper is not to assess whether the EU has a just security strategy, since such an exercise is problematic 
both in terms of operationalisation and in overall scientific merit. A security strategy is in most cases carefully drafted to reflect and protect certain interests and can generally be interpreted as 'just' by those who benefit from it. Similarly it may well be denounced as 'unjust' by any actors that deem themselves to be adversely impacted notwithstanding the legitimacy or otherwise of their own justice claims.

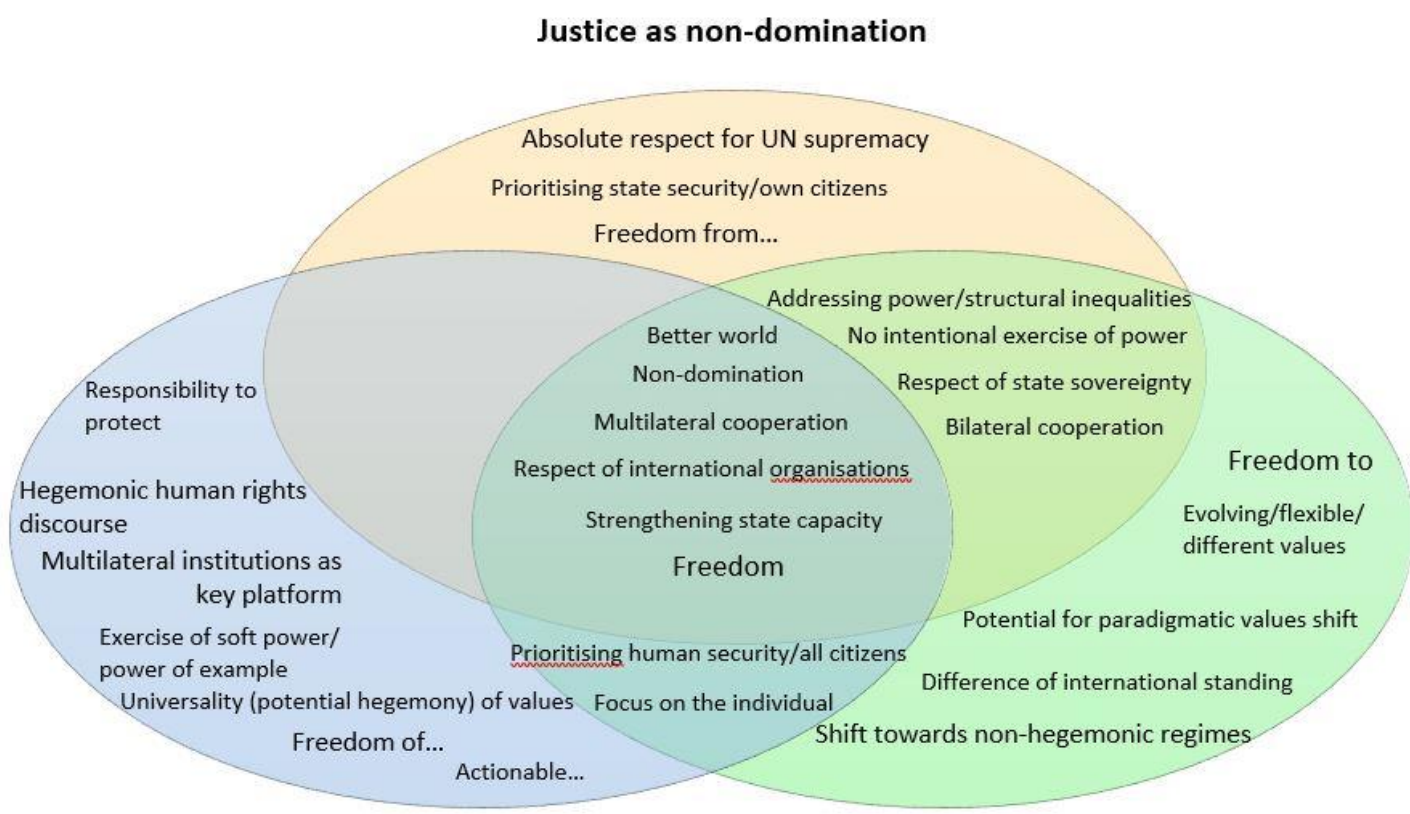

Justice as impartiality

Justice as mutual recognition

Figure 1: Venn diagram of global justice descriptors

Broad security strategies like those drafted by the EU focus on a vast number of issues, areas, actors, and follow a (self-)prescribed normative framework (e.g. 'A Secure Europe in a Better World', emphasis added by authors). It is therefore almost tautological to ask whether the EU's security strategy is just, as several indicators of justice can be found within and the answer is affirmative in one way or another. The distinction between the three concepts of justice enables us to identify different trajectories in the EU's strategic discourse, and to better understand how the EU contributes to global justice and what type of global justice is prioritised in the EU's strategic thought. It is important to note that neither Eriksen nor the authors here prioritise one conceptualisation of justice over another. Neither type of justice is more just, they merely prescribe different approaches to how justice is achieved. Moreover, while each conception has its own internal logic and consistency, each also suffers from specific lacunae and/or faces profound challenges in its operationalisation through a real-world foreign, security and defence policy. In terms of operationalisation of this research, the distinction provides a valuable set of descriptors and indicators of a just global order. The three conceptions of global justice, even in their abstract form are not completely different from each other, and share 
certain elements, like the absence of dominance, equality and freedom. Applied to the reality of global politics and translated into the vocabulary of international relations, the overlap is even starker. The Venn diagram above (Figure 1) depicts the overlaps of the different descriptors of the three ideal types of justice identified in the conceptual discussion in the previous three sections of this paper. It is only when the conceptual discussion teases out the outliers and incommensurable indicators of the different conceptions of justice that one can start effectively analysing the EU's strategic discourse. By doing so, the discourse analysis ignores the broad overlapping descriptors of justice, which represent the same tautological discursive space in the EU's security strategy. Without focusing on the outliers, everything in the discourse can be interpreted as describing a just world order. These outliers act as systematically chosen deductive codes that the coding process can focus on and are listed below.

Non-domination:

1. Absolute respect for UN supremacy

2. Prioritising state security and the security of own citizens

3. Freedom from...

Impartiality:

1. Multilateral institutions as key vehicles for protection of universal values

2. Hegemonic human rights discourse

3. Universality of values is absolute

4. Universal values are to be instantiated and actionable

5. Exercise of hard power and the responsibility to protect

6. Exercise of soft power/power of example

7. Freedom of...

Mutual recognition:

1. Shift towards non-hegemonic regimes and international institutions

2. Potential for paradigmatic value shifts

3. Evolving, flexible and contested values

4. Difference in international standing

5. Freedom to...

Before testing these the views of justice on the EU's security strategy documents, it is necessary to review the institutional and historical context of the EU as a foreign policy actor in general and the contexts of the three different strategic documents in particular.

\section{EU foreign policy and 'values"}

One of the remarkable features of both the study of EU foreign and security policy and its execution, is the focus which is given to norms and values therein. As we assess the Union's treatment of 'justice' as a key norm of its foreign and security policy, it is 
important that we also map and understand the significance of such values within EU foreign policy more broadly. While no foreign policy could likely be described as 'valuesfree', the extent to which the European Union's international engagement is seen or claimed to be motivated and defined by a prescribed set of underlying norms is remarkable. This is in part - perhaps even largely - due to the very uniqueness of the Union as a polity comprising 28 sovereign actors. While the Union has accreted many of the forms and functions of an international actor, through the development of foreign policy structures and decision-making processes, it remains subject to the sovereign will of its Member States and rests upon a legal underpinning firmly rooted in intergovernmental cooperation. Nonetheless, the office of the High Representative and Vice President of the Commission (HRVP) and the European External Action Service (EEAS) now preside over a complex institutional structure which can deliver the substance of a collective foreign and security policy to its Member States.

The trajectory of this development has also caused some difficulty for analysts. Initially devoid of an explicit foreign policy function (save for the nearly unmediated external impact of its creation as an economic trading bloc) the antecedent European Communities only slowly developed cooperation in the field of foreign and security policy. Initially, this was seen as developing a new kind of international actor; one devoid of some of the traditional accoutrements of 'power' such as military capacity, and relying instead on diplomacy and economic tools to achieve foreign policy ends. This new kind of international actor or 'civilian power' (Dûchene 1973: 19) could indeed be seen as an innovation, presaging a fundamental shift in the dynamics of global politics. Conversely, Europe's very 'civilianness' could also be presented as critical deficiency, crying out for the development a full-blooded foreign policy capacity including an appropriate military power dimension (Bull 1982).

This dual paradox; the unique nature of the Union as an international actor mapped onto the ongoing iterative development of its foreign, security and defence policies has presented scholars with both an ill-defined and moving target for analysis. In response, such analysts have struggled to develop terms to encompass the Union within the known universe of the international system. These have included defining Europe as a gentle power (Merlini 2001; Padoa-Schioppa 2001), a quiet superpower (Moravcsik 2009), a postmodern actor (Kagan 2003; McCormick 2009, a liberal power (Rynning 2003), a responsible power (Mayer and Vogt 2006), an ethical power (Aggestam 2008), and a pragmatic power (Wood 2010). At root, each of these formulations is highlighting the problematic duality of an actor which is profoundly 'different' from the traditional Westphalian states which comprise the global system (and indeed the EU itself) and which at the same time continues to evolve as a foreign policy actor in its own right, adding new competences and policy making structures while raising its own expectations for foreign policy effectiveness and coherence.

It is also useful to remind ourselves that many of the 'values' now ascribed to the Union in its international action, inter alia, the promotion of democracy, the defence of human rights and a commitment to the rule of law, were not explicit at its foundation as the 
European Communities. Indeed, there were vigorous debates in the 1960 s as to whether or not it was even necessary for a European state, capable of undertaking the economic obligations of membership, to be a functioning democracy (Hebel and Lenz, 2016). Thus, it is at least problematic to ascribe the Union's 'difference' as an actor directly to a specific set of values and norms.

Nonetheless, in contemporary analyses, the notion that the European Union can best be understood as a unique values-driven actor is a powerful one and one which is profoundly reflected in the foreign policy discourse of the Union itself. At its zenith, the Union is described as an engine of global transformation and one which is dedicated to '[...] taming power politics' (Sjursen 2015: 204) or even transforming consideration of what is 'normal' in global politics (Manners 2002). This is seen to derive specifically from the history of European integration and its genesis as a continental peace project, its nature as a hybrid polity (situated between statehood and an intergovernmental organisation), and its constitutional/legal structure which serves to project internal norms such as dedication to the rule of law, to the international arena.

With values seen to be core to a contemporary understanding of EU foreign policy, it is useful briefly to set out their derivation and definition. Lucarelli and Manners (2006) have identified as the Union's core values those of peace, human rights, freedom/liberty, democracy, equality, justice/rule of law and solidarity. Subsidiary rights derived from these include good governance/effective regulation, ecological modernisation and sustainable development. They argue that while these are not unique to the European Union, their relative importance in policy making and their effective translation into policy principles are exceptional. Taken together, they create of the Union a singular international actor with the ambition to transform the international system and which envisages '[...] the opportunity for pacific transformation of international relations into a world politics for the better [...]' (ibid: 203). Moreover, they insist that it in the absence of a legitimating sovereignty of its own, it is these very values which serve as the constituting force of the Union as an international actor: they legitimate the Union as an actor and justify and animate its international action (ibid: 212).

It is clear too, that over time these values have been deeply instantiated in the political and constitutional foundations of the Union, arguably starting with the 1970 Davignon Report, which established the first tentative steps in foreign policy cooperation. That document, commissioned by the Heads of State and delivered by the Member State foreign ministers, sought to create a '[...] united Europe capable of assuming its responsibilities in the world of tomorrow and of making a contribution commensurate with its traditions and its mission'. These were defined in relatively vague terms such as 'the relaxation of international tension and the rapprochement among all peoples' and 'setting international relations on a basis of trust' but they were rooted in a clear declaration that the Member States shared a 'common heritage of respect for the liberty and rights of man' and that they represented 'democratic States with freely elected parliaments'. 
This somewhat hesitant start was reinforced just three years later by the Copenhagen Declaration on European Identity (1988), in which the then nine European foreign ministers set out a definition of their relations with other countries and the place of their region of Europe in world affairs. Therein, they framed their dedication to values such as democracy, the rule of law and social justice in essentially self-protective terms to ensure that their shared values were 'respected' and defended and that their national cultures were 'preserve(d)'. Critically, they insisted that they were not 'inspired by a desire for power'. Moreover, while they sought to 'to exert a positive influence on world economic relations with a view to the greater well-being of all' they did not seek to promote their own values internationally, instead insisting that they sought to cooperate for mutual benefit with all countries 'whatever their size, culture or social system'.

The 1986 Single European Act (SEA) moved this position forward only slightly, anxious now that the European Communities would 'display the principles of democracy and compliance with the law and with human rights to which they are attached' (1986: 5). Presumably in that 'display' they sought to present themselves as an exemplification of best practice - perhaps as an early progenitor of 'soft power' (Nye 2004: 5) There was certainly no suggestion in Title III of the SEA - which for the first time in treaty form set out the mechanisms underpinning foreign policy cooperation - that these European states were embarked on any mission to disseminate or promote their shared values externally. Their ambitions were limited to making a contribution to the "preservation (emphasis added) of international peace and security' within the existing UN context, rather than any transformation of the international system.

With the post-Cold War Maastricht and Lisbon treaties, however, we see the flowering of European normative ambitions. The Maastricht Treaty, while reiterating ambitions to 'safeguard', 'strengthen' and 'preserve' now also sought to 'develop and consolidate democracy and the rule of law, and respect for human rights and fundamental freedoms' internationally as well as 'to promote peace, security and progress in Europe and in the world' Official Journal of the European Communities 2002). The Lisbon Treaty goes much further still, asserting the centrality of 'the universal values of the inviolable and inalienable rights of the human person, freedom, democracy, equality and the rule of law,' and dedicating the EU to 'advance in the wider world' the principles which are said to have inspired its own creation, development and enlargement, namely 'democracy, the rule of law, the universality and indivisibility of human rights and fundamental freedoms, respect for human dignity, the principles of equality and solidarity, and respect for the principles of the United Nations Charter and international law' (Official Journal of the European Union 2007). It also explicitly privileged relationships with those states and organisations sharing the aforementioned values and norms.

Significantly too, the Lisbon Treaty goes much further in specifying the level of the Union's normative ambitions, now framed in terms of supporting, fostering, encouraging, promoting, helping and assisting change across a wide range of thematic areas including international security, the environment, socio-economic development, natural disasters, multilateral cooperation, human rights and democracy. 
In sum, it appears to be clear that while both contemporary practitioners and analysts posit the Union as a unique actor with a singular commitment to a well-defined set of values, it is at least problematic to assume that ontology determines either orienttation/behaviour or even the range of what may be possible in terms of foreign policy. Instead, it is significant to remind ourselves that the development of the Union's values has its own complex narrative and that this may be usefully read through at least some of its founding documents. As a result, with a narrowing of focus to a single value (that of the pursuit of global 'justice') and concentration on a single inter-related set of highlevel policy documents (security strategies) we may usefully begin to interrogate the Union's treatment of that value and its centrality (or otherwise) to EU foreign policy.

\section{Context and significance of strategy statements}

'Strategy' entails planning for goals. For an international actor, a foreign policy or security strategy is a high-level public document designed to define the means by which that actor intends to deploy available assets to achieve specified ends. This will usually be done within the context of specifying the challenges/threats faced by that actor and drawing upon the norms/values which are privileged by that actor. Bearing in mind the conversation above on the role of values in EU foreign policy, we can also note that in the case of the European Union and its security strategy, we can see how these values defines the Union's legitimacy and its very identity. Thus, these strategy documents are a profound source of clarity on how the Union and its Member States see themselves within the global commons, how they define themselves and what they set as priorities in their dealings with third countries and the broader international system as a whole. Moreover, as we shall see, Member States and EU-level policy actors undertake such endeavours with considerable circumspection and seriousness, again underlying their significance and import.

\section{'A Secure Europe in a Better World - The European Security Strategy' (2003)}

The context for the drawing up of the Union's first security strategy in 2003 was one of crisis. While analysts and some practitioners had long sought the delineation of a broad strategic vision which might direct the European Security and Defence Policy (ESDP) from the 1999 Cologne European Council, Member States had demurred. For most, the cost/benefit analysis of embarking upon an introspective analysis to draw up a document of uncertain significance was not worth the effort. For the less ambitious, it was argued to be premature to talk about the Union's 'strategy'. For the more ambitious, there was argued to be too much yet to do in the here and now, to devote limited attention to an essentially theoretical exercise. For their part, critics insisted that the absence of such a strategic vision in EU external action highlighted a lack of 'direction, determination and consistency' (Biscop 2004: 4). 
In the event, the crisis surrounding the 2003 US-led invasion of Iraq engulfed the Union in its own diplomatic crisis, with the drawing up of an agreed security strategy deemed to be the means by which those internal divisions, and those which had opened between Europe and the United States, might be ameliorated.

US policy towards Iraq in 2002-2003 had bitterly divided European governments, to the extent that EU Member State ambassadors within the UN Security Council traded allegation and counter allegation. For their part, the heads of governments from Czech Republic, Denmark, Hungary, Italy, Poland, Portugal, Spain, and the UK had issued a public letter pledging support for the US approach to Iraq while the 'Vilnius 10' of central European states - on the cusp of joining the EU themselves - had similarly pledged their support. This latter initiative drew a bitter public rebuke from the French President, Jacques Chirac on the 'dangers' of their allying themselves too quickly to the US. Meanwhile France and Germany were steadfast in their opposition to US policy to turn to military force and they were joined by Belgium and Luxembourg at a mini-defence summit in that year to discuss how to develop an autonomous European defence capacity.

The crisis had also undercut transatlantic relations. The US Defence Secretary, Donald Rumsfeld, publically celebrated support from the 'new' European family of states and with near equal enthusiasm, dismissed the opposition of what he dubbed 'old' Europe, i.e. France and Germany. He went on later to suggest that in the new security environment, the United States might need the support of specific allies for specific missions - comments widely viewed as suggesting the US would cherry-pick its support, weakening the collective integrity of NATO. By the time of the US invasion in February 2003, the transatlantic relationship was suffering through the "most venomous climate in living memory' (Toje 2005: 131).

Thus, when EU foreign ministers gathered on the island of Rhodes for one of their informal 'Gymnich-style' meetings in May 2003, there were a number of heavily scorched bridges in need of repair. There, the Union's High Representative for foreign and security policy, Javier Solana, was tasked with the writing of a 'strategic concept' for the Union. This was designed to address three requirements: (i) to provide EU Member States with an agreed foundation for the development of their shared foreign and security policy, (ii) to bind the wounds of Member States in the aftermath of the US-led invasion of Iraq and (iii) to restore equanimity in bilateral EU-US relations in the foreign and security policy realm.

The working method underpinning this endeavour and the mandate itself was said to have been 'engineered' by Solana and his staff (Anderson et al 2011: 6). A small team centred on Robert Cooper, Director-General, Politico-Military Affairs in the Council Secretariat and Christoph Heusgen, Director of the Policy Planning and Early Warning Unit in the Council Secretariat worked on a draft which was successfully presented at the 19 June Thessalonika summit. Following discussion there, the High Representative was invited to refine the text further so as to 'encapsulate member states' interests and citizens' priorities' (Andersson et al. 2011: 19). This was accomplished over a series of 
three seminars organised by the EU Institute for Security Studies, bringing together a cross-section of officials, politicians, diplomats, military personnel, academics, journalists and civil society leaders. Following revisions, the text was adopted at the December 2003 EU Council summit.

The new strategy document was widely seen as providing the Union with a distinctive strategic vision, but also one which spoke deliberately to the US' own National Security Strategy. Having been written in a strikingly limited time frame, the strategy defined the Union in unique terms, and in a context in which Europe had never been 'so prosperous, so secure, nor so free' (European Council 2003: 27). It defined a strong international liberal order and celebrated the potential of a Union in an international system where soft power could be seen as being in the ascendant. It was also praised as being an exceptionally accessible document which successfully reflected Europe's new security environment but which was as yet missing a definitive exposition of Europe's means and policies (Andersson et al. 2011). Its core innovations centred upon the delineation of a 'comprehensive approach' towards security and the integration of internal and external aspects of security such as in the realm of terrorism.

\section{'Report on the Implementation of the European Security Strategy - Providing Security in a Changing World" (2008)}

Five years after the publication of the European Security Strategy, Europe was certainly in a different strategic space. Following the 2004 enlargement, the Union now bordered the Russian Federation and comprised a total of 27 Member States. The new Lisbon Treaty, with its reinforced post of High Representative and Commission Vice President (HRVP) and the proposed External Action Service had been signed and the world had been plunged into a major financial and economic crisis.

Over the autumn of 2007, Swedish Foreign Minister Carl Bildt and French President Nikolas Sarkozy had separately called for a review of the Union's security strategy, with Bildt in particular pointing to Russia's evolution and the need for the Union to revisit its strategic approach (Biscop, Howarth and Giegerich 2009: 38). For his part, Sarkozy saw such a review as an opportunity to draw EU and NATO closer as part of a deeper reset of transatlantic relations. Germany and others were reluctant. Post enlargement, a redraft risked making even more visible the significant rifts which already existed between old and new member states' approach to Russia. Solana too was reluctant (Andersson et al. 2011). but eventually a mandate "to examine the implementation of the Strategy with a view to proposing elements on how to improve the implementation and, as appropriate, elements to complement it' (European Council 2007: pt. 89), was agreed at the December 2007 EU Council summit.

The political context of the review only worsened over 2008, with the August RussoGeorgian war heightening concerns among many newer EU Member States. By September, following the August 2008 hostilities, the EU heads of government were 
talking about a 'crossroads' in Europe's relationship with Russia. Nonetheless, over the second half of 2008 four expert seminars were organised again by the European Union Institute for Security Studies (EUISS) in Rome, Natolin, Helsinki and Paris to discuss and to review the security strategy. In the absence of any draft document, those events served to widen the parameters of discussion rather than to focus debate. The drafting team on this occasion was much larger, including a variety of institutional representatives as well as a mix of academics, analysts and practitioners. the 'Report on the Implementation of the European Security Strategy - Providing Security in a Changing World', was adopted by the EU Council at their December 2008 summit.

The Implementation Report as it became known, noted that 'despite all that has been achieved, implementation of the ESS remains a work in progress' (European Council 2008: 2). It included no direct follow up or action plan, but insisted that 'we must do more to shape events. And we must do it now' (ibid: 12). Substantively, the report highlighted additional areas of security concern such as climate change, cyber security and health pandemics.

\section{'Shared Vision, Common Action: A stronger Europe, a Global Strategy for the European Union's Foreign and Security Policy' (2016)}

On her appointment and in her confirmation hearing at the European Parliament in September 2014, the incoming High Representative and Vice President of the Commission (HRVP), Federica Mogherini, signalled what she saw as the need to initiate a process of 'strategic reflection' within the EU. Even as Italian Foreign Minister she had bridled at the tendency of the Union's foreign policy focus to jump from crisis to crisis (Tocci 2016: 461) and the apparent lack of a deeply instantiated sense of strategic direction. She sought, however, a very different kind of strategic statement from that of 2003, not least deriving from a context of profound existential threat.

That crisis derived from within a without. From within, the Union faced the rise of radical nationalist/populist politics in many member states, the accelerating debate within the UK on withdrawal from the EU, the continuing impact of the economic crisis and ongoing austerity politics and a general weakening of trust in European political institutions at all levels. Externally, the Union faced the obvious security challenges of terrorism, serious armed conflicts in the immediate European neighbourhood, an emboldened and aggressive Russia, the humanitarian challenge of mass migration from the Middle East and North Africa and shifting geopolitical balances. Among the Member States, there were also multiple and cross cutting cleavages to be addressed. For Mogherini, this necessitated a different working method.

The 2003 and 2008 processes had led to documents being 'adopted' by the European Council. These were statements drafted by the High Representative and his team, but ultimately for and on behalf of the Member States. With the new institutional structures 
of the Lisbon Treaty in operation it made more tactical sense to see this process rooted more firmly in the Union's own policy infrastructure and with the Member States as the core partners in that endeavour.

On taking office, the new HRVP already had a mandate to undertake an assessment of 'the impact of changes in the global environment'. This had been agreed at the December 2013 EU Council summit as part of a wider dedicated discussion of strengthening the Union's security and defence capacity. Eschewing the possibility of 'twisting' that mandate into the pursuit of a full-blown strategy statement - an effort which would likely also have strained to breaking point her then tentative relations with Member State capitals - the HRVP played a longer game. Over eight months, deploying the capacity of the EEAS, Commission and EUISS, the HRVP's team developed a review of the Union's strategic environment so as to define the context within which any new EU strategy would have to be developed. The resulting document; 'The European Union in a Changing Environment', was delivered to the June 2015 EU Council summit.

For the HRVP's team this was a useful trial run for the larger envisaged project of a new 'global' strategy document. (Tocci 2016: 463). With the scene thus set and the confidence of the Member States secured, the HRVP had her dedicated mandate in June 2015 to 'continue the process of strategic reflection with a view to preparing an EU global strategy on foreign and security policy in close cooperation with Member States' (European Council 2015: 5). For the HRVP the term 'global' was critical, allowing her team the capacity to weave together the threads of the Union's international capacity to identify both goals and means across the entire range of the Union's global engagement. Moreover, as master of the process, the HRVP was free to devise a working method in which she prioritised broad expert and public engagement - the scale of which even surprised her closest advisors (Tocci 2016: 466).

An extensive public outreach programme ultimately entailed more than 50 formal events across the member states with the active participation of all foreign ministries. Operating in parallel to formal Common Foreign and Security Policy (CFSP) structures, through a network of informal Points of Contact in each foreign ministry, Member States were kept close to the project but outside the immediate drafting loop. Extensive use too was made of expert groups, academics and specialists from within the Commission and EEAS. As the end date neared, engagement with member states intensified - but always somewhat at arm's length. This was achieved through, for example, the use of disseminated chapter 'summaries' which allowed for substantive discussion but not textual amendment, and ultimately 'confessionals' where member states could review and comment on draft text but could not transmit or share the text with others.

As a core member of the drafting team, Nathalie Tocci notes that the while the underlying philosophy and structure of the strategy were definitively those of the HRVP and her team, the 'flesh on the bones' came from Member States, the Commission, and the wider foreign policy community through the aforementioned public outreach and broad consultation. Arising from this, the strongest points of underlying consensus and 
ambition centred on security and defence, as a 'critical mass' of Member States were ready and willing to 'press the accelerator' in this area (Tocci 2016: 468).

Due in part to the nature of the working method adopted, the June 2016 submission of the new Global Strategy; would not have been expected to be 'adopted' by the Member States. Instead the options were to 'note' or to 'welcome' the HRVP's text. In the event the HRVP's presentation was indeed welcomed and, significantly, she was given the green light to take the work forward, ultimately resulting in a detailed implementation process.

\section{Visibility of the conceptions of justice across the three documents}

The three strategy documents represent both a discursive manifestation of the EU's foreign policy nature and identity (as discussed in section 2) and the particular concerns and goals of the EU in the given historical and political contexts within which these strategies were written (as discussed in section 3). The documents do not explicitly and solely focus on global justice, and the term 'justice' is used in a more narrow (legal) sense as well as more sparsely. In order to assess the EU's contribution to global justice based on its strategic view, it was therefore necessary to analyse the three strategic documents more thoroughly and interpret the texts in light of their historical and institutional contexts.

A qualitative content analysis and double-coding of the text highlighted themes, concepts and narratives in the EU's strategic thinking that reflect both the EU's norms and values, as well as concrete concerns and threat perceptions. These themes, concepts and narratives correspond with the deductive codes (descriptors) of the three types of just foreign policy identified in the conceptual discussion above (section 1). A first read of the EU's three strategic documents reveals several instances of explicit or implicit concern of the EU with elements of non-domination, impartiality or mutual recognition, but in the majority of instances the concerns overlap with each other. When analysing the EU's strategy documents, one must be careful not to confuse certain passages as indicating one approach to justice with another. A case in point is the EU's concern with good governance. This concern can be interpreted as both a desire for strong states capable of governing and protecting its citizens (non-domination) or, understood in a more normative sense, as an emphasis on the nature (goodness) of governance, which, as elaborated in the documents assumes the respect and protection of universal rights and freedoms of individuals (impartiality).

Another example is the EU's concern with local ownership. The Global Strategy, for instance, explains that working with local authorities can 'also improve [the EU's] local knowledge, helping [the EU] distinguish between those groups [it] will talk to without supporting, and those [it] will actively support as champions of human security and reconciliation' (EEAS 2016: 31). While the focus on acquiring local knowledge is indicative of learning and mutual recognition, the fact that the EU will select who it will support and who it will not support echoes more the EU's selective partnering based on shared 
values and choosing 'like-minded champions' of values that the EU perceives as commonly accepted and universal (as indicative of justice as impartiality).

As explicated above, such broad themes that correspond to overlapping descriptors of the different conceptualisations of justice have little value in determining the trajectory of the EU's strategic thinking in relation to justice. The analysis therefore focuses on the specified outlying descriptors of justice as non-domination, impartiality and mutual recognition that are incommensurable and unique to the different conceptions of justice. The findings of the analysis and how these themes and concepts correspond to the outlying descriptors of justice as non-domination, impartiality and mutual recognition are systematically presented in the tables below. The tables indicate the relative occurrence of the deductive codes in the different texts, ranging from 'none', 'marginal', 'some' to 'substantial'.

\section{Justice as non-domination}

An EU strategy in line with justice as non-domination ought to focus heavily on protecting and securing the sovereignty of the EU's own member states, but also on aiding other states to become secure, strong and well-governed states, and preserving a stable international, UN-based system of sovereign states in which intervention (and domination) is avoided. It ought to emphasise the security of the EU's citizens and posit freedom from aggression by others as a key imperative. The EU's Security Strategy from 2003 outright establishes that 'Large-scale aggression against any Member State is now improbable' (European Council 2003: 3). Instead, the document considered terrorism as the key new threat to EU citizens' security and freedom. As the EU's 2003 strategy notes, 'our traditional concept of self-defence - up to and including the Cold War - was based on the threat of invasion. With the new threats, the first line of defence will often be abroad' (ibid: 7). The strategy stressed the importance of well-governed, stable states and identified 'state failure' as the root cause of other key threats like terrorism, regional conflict and organised crime (ibid: 4).

The strategic review document from 2008 echoes the EU's focus on a stable international system based on sovereign states: 'Sovereign governments must take responsibility for the consequences of their actions and hold a shared responsibility to protect populations from genocide, war crimes, ethnic cleansing and crimes against humanity' (European Council 2008: 2). Furthermore, in the 2008 document (following conflicts over the territory of Kosovo and concomitant to conflicts in South Ossetia and Abkhazia) the strategy also stresses that the EU 'must be clear that respect for the sovereignty, independence and territorial integrity of states and the peaceful settlement of disputes are not negotiable. Threat or use of military force cannot be allowed to solve territorial issues - anywhere' (ibid: 2). The focus on peaceful settlement of disputes and strong sovereign states that are capable of preserving peace both correspond to the freedom from aggression imperative of justice as non-domination. 
Overall, the descriptors of justice as non-domination are found sporadically and often alongside descriptors of justice as impartiality. The EU proclaims that it needs to both 'defend its security and to promote its values' (European Council 2003: 6). This is particularly observable in relation to the EU's stance on the role of the UN. The UN is referred to as both a bulwark of state sovereignty and as a protector of universal rights and freedoms. The importance of sovereignty over universality slightly increases from 2003 to 2016, as the importance of citizen security takes priority during the same period, resulting in a more substantial emphasis on terrorist threats and the security of people within Europe, not just beyond. Narratives of freedom from aggression, dominance and intervention decrease through the different documents, as the EU becomes more keen to project power globally, which inevitably opposes justice as non-domination.

Table 1: Justice as non-domination in EU security strategy documents

\begin{tabular}{|c|c|c|c|}
\hline Descriptors (justice as non-domination) & ESS 2003 & RIESS 2008 & GS 2016 \\
\hline Absolute respect for UN supremacy & Marginal & Some & Some \\
\hline $\begin{array}{l}\text { Prioritising state security and the security of } \\
\text { own citizens }\end{array}$ & Some & Some & Substantial \\
\hline Freedom from... & Some & Marginal & Marginal \\
\hline
\end{tabular}

\section{Justice as impartiality}

As explained above, a view of justice as impartiality in the EU strategic documents is closely tied to that of justice as non-domination. The EU finds no contradiction between the importance of state sovereignty and securing one's own citizens and breaching other states' sovereignty with the goal of reforming, strengthening, or otherwise changing the functioning of third states. The narrative that allows for this is based on the premise, particularly present in the Global Strategy (2016), that the problems the EU faces are shared with the rest of the world. Providing security globally means securing Europe's own citizens. As the Security Strategy (2003) states 'our security and prosperity increasingly depend on an effective multilateral system' (European Council 2003: 9). In the same document, the EU acknowledges that neither the EU nor indeed any single country '[...] is able to tackle today's complex problems on its own' (ibid: 1). The strategy frequently paraphrases one message, namely that 'the EU is committed to achieving universal adherence to multilateral treaty regimes, [...] strengthening the treaties and their verification provisions' (ibid: 6). The EU wants 'international organisations, regimes and treaties to be effective' (ibid: 9). Their view of a secure world is one with 'an effective multilateral system [...] a stronger international society, well-functioning international institutions and a rule-based international order' (ibid: 9).

The main pillar of such an institutional and rule-based order is, according to the EU strategy, to be found in the United Nations, which it repeatedly (if not repetitively) emphasises in its strategic documents. This in particular applies to both 'responding' to threats and 'preventive engagement' (ibid: 11) in countries facing instability and conflict. 
As the 2008 review document states, 'everything the EU has done in the field of security has been linked to UN objectives' (European Council 2008: 11). In the world of impartiality, sovereignty comes second to strengthening 'international justice and human rights' and issues that 'cross boundaries, touching as much on domestic as foreign policy' (ibid: 12). In an impartial view of justice, human rights trump sovereignty. Moreover, 'sovereignty entails responsibility, [...] a shared responsibility to protect populations from genocide, war crimes, ethnic cleansing and crimes against humanity' (ibid: 12). The 'responsibility to protect' rhetoric in the documents is at times at odds with the call for stronger sovereign states and with a conceptualisation of justice as non-domination.

The human rights discourse gradually increases in salience over time. The Security Strategy (2003) ties human rights protection with 'spreading good governance' as 'the best means of strengthening the international order' (European Council 2003: 10). In the report on the implementation of the Security Strategy (2008), the EU increases its emphasis on human rights and stresses the 'need to continue mainstreaming human rights issues in all activities' (European Council 2008: 10). With the Global Strategy (2016), which is significantly more introspective in nature, human rights concerns are linked with the notion of resilience both globally and locally. In the 2016 document, the EU reiterates that it 'will foster the resilience of its democracies, and live up to the values that have inspired its creation and development' (EEAS 2016: 8). The Global Strategy presents these values as global and uncontested. In the same document, 'promotion of human rights, fundamental freedoms and the rule of law, [...] justice, solidarity, equality, non-discrimination, pluralism, and respect for diversity' (ibid: 15) are all envisaged in both Europe and beyond.

While the EU posits universal rights and fundamental freedom as absolute and paramount to international security, the security strategies do not reflect in greater detail about why and how these freedoms do so. However, the strategy statements imply that these imperatives are to be actionable and the Union is presented therein as a significant actor in this endeavour. In the 2008 document, the EU claims it is 'recognised as an important contributor to a better world' (European Council 2008: 2), but in the most recent document, the EU goes a step further claim it

[...] always prided itself on its soft power [...] because [it is] the best in this field. However, the idea that Europe is an exclusively 'civilian power' does not do justice to an evolving reality. [...] For Europe, soft and hard power go hand in hand.

(EEAS 2016: 4).

Overall, the EU has consistently held a strong view sustaining an impartial, rule-based order with universal values, fundamental freedoms and human rights at its core, although it does not reflect significantly on the underlying provenance of those values. Over time, however, it increasingly positioned itself as a major contributor to an impartial just world order, at first with the deployment of its 'soft power', but most recently, in the Global Strategy, also as a 'global security provider' (EEAS 2016: 3), as an 
actor that can actively intervene to promote and defend universal values and fundamental freedoms.

Table 2: Justice as impartiality in EU security strategy documents

\begin{tabular}{|l|l|l|l|}
\hline Descriptors (justice as impartiality) & ESS 2003 & RIESS 2008 & GS 2016 \\
\hline $\begin{array}{l}\text { Multilateral institutions as key vehicle for } \\
\text { protection of universal values }\end{array}$ & Substantial & Substantial & Substantial \\
Hegemonic human rights discourse & Some & Substantial & Substantial \\
$\begin{array}{l}\text { Universality of values is absolute } \\
\text { Universal values are to be instantiated and } \\
\text { actionable }\end{array}$ & Some & Some & Some \\
$\begin{array}{l}\text { Exercise of hard power and the responsibility } \\
\text { to protect }\end{array}$ & Some & Substantial & Substantial \\
$\begin{array}{l}\text { Exercise of soft power/power of example } \\
\text { Freedom of... }\end{array}$ & Substantial & Substantial & Some \\
\hline
\end{tabular}

\section{Justice as mutual recognition}

The paradox of intervention without domination has not been fully resolved. This is mostly due to the fact that the EU and its neighbours are not facing the same challenges. The differences between the EU member states and its societies and states and societies in its geographic neighbourhood are visible both in the inequality of status and equality of access to protection of universally agreed norms and values. In this sense, justice as impartiality assumes intervention as being necessary. It is not unjust and it is not a form of dominance if the goal is to secure equal access to universal and fundamental rights. The EU therefore plans to "partner selectively with players whose cooperation is necessary to deliver global public goods and address common challenges' (EEAS 2016: 18). By only cooperating with 'like-minded countries and regional groupings' (ibid), the EU runs the risk of acting unjustly, according to the conceptualisation of justice as mutual recognition. Justice as mutual recognition emphasises that difference is inevitable and that different participants should have equal access to contributing to the commonly agreed goals and norms.

Significantly, the inclusion of voices of 'the other' was predominantly absent from the 2003 and 2008 strategies. The 2003 strategy has no explicit view on either difference or recognition of others. Its emphasis on partners and cooperation does not sufficiently define the nature of the relationship between the EU and its (apparently like-minded) partners. The closest this document comes to acknowledging the input of other countries is in its view on the Arab/Israeli conflict, which the EU envisions resolved only through a 'cooperative effort' by 'above all [...] the Israelis and Palestinians themselves' (European Council 2003: 8). 
Brief mention of 'inter-cultural dialogue, through such fora as the Alliance of Civilisations' is found in the 2008 strategic review (European Council 2008: 4), but other more explicit acknowledgment of cultural uniqueness or difference is absent. Only with the Global Strategy of 2016 do we observe a potentially significant shift towards recognising the importance to 'reach out more to cultural organisations, religious communities, social partners and human rights defenders', as well as greater emphasis on 'deepening work on education, culture and youth to foster pluralism, coexistence and respect' (EEAS 2016: 27).

Local ownership reveals, in particular, that the EU seeks to 'support cooperative regional orders worldwide' as well as 'voluntary forms of regional governance' that 'offer states and peoples the opportunity to [...] express more fully cultures and identities, and project influence in world affairs' (ibid: 10).

Table 3: Justice as mutual recognition in EU security strategy documents

\begin{tabular}{|l|l|l|l|}
\hline Descriptors (justice as mutual recognition) & ESS 2003 & RIESS 2008 & GS 2016 \\
\hline $\begin{array}{l}\text { Shift towards non-hegemonic regimes and } \\
\text { international Institutions }\end{array}$ & None & Some & Some \\
Potential for paradigmatic value shifts & Marginal & Marginal & Marginal \\
Evolving, flexible and contested values & Marginal & Marginal & Some \\
Difference in international standing & None & Some & Some \\
Freedom to... & None & None & None \\
\hline
\end{tabular}

\section{Conclusion}

The capacity and ambition of the EU to be 'just' has changed over time, as its influence and place in the world has also changed. Furthermore, the three different security strategies served very different purposes within their respective historical contexts and within the ongoing institutional and political evolution of EU foreign policy. The first two documents gravitated towards legitimising and strengthening the very existence of EU foreign policy, while the Global Strategy has aimed to consolidate the EU as an actor in global affairs, which is reflected in the respective narratives of these documents. In the former two, the EU noticeably focuses more on effective multilateralism and equal partnership. The EU, at the time when these documents were written, was much more reliant on engagement with other partners like the UN and NATO. If compared to the more projecting self-image of the EU leading by example identified in the Global Strategy, one can observe the evolution of the EU's foreign policy into being characterised by a degree of autonomy and (self-proclaimed) uniqueness in approach.

Assessing the EU's ability to act as a global foreign policy actor is however not equivalent to assessing the EU's contribution to global justice. Judging on the tables and findings of the analysis above, we see a shift of the EU's foreign policy discourse from 'justice as impartiality' towards combined elements of 'justice as non-domination' and 'justice as 
mutual recognition'. This shift is illustrated in the table below. Table 4 presents the prominence of descriptors of the respective conceptions of justice in the different security strategies (yes $(\mathrm{Y})$, prominent or no $(\mathrm{N})$, not prominent). One potentially problematic observation in the findings stands out. The EU's support for 'stronger' sovereign states runs parallel to its support of intervention through multilateral channels (against the principle of state sovereignty), and with the Global Strategy a third line of support for local ownership in third countries can be observed. This calls into question both the pragmatism and the principle of the EU's foreign policy strategy. Is it possible to 'prevent' state failure and future intervention through intervention, while at the same time calling for local ownership of the intervention? Is such a policy just and if yes, with which conception of justice is it compatible?

Table 4: Summary of conceptions of justice in EU security strategy documents

\begin{tabular}{|l|l|l|l|}
\hline Conceptions of justice & ESS 2003 & RIESS 2008 & GS 2016 \\
\hline Justice as non-domination & Y & Y & Y \\
Justice as impartiality & Y & Y & Y \\
Justice as mutual recognition & N & N & Y \\
\hline
\end{tabular}

Of similar significance is the ambiguity surrounding key justice-related concepts such as resilience and local ownership. As suggested above, such concepts can have multiple meanings and be deployed in significantly different ways to different audiences. Local ownership, for example, has the potential to be a ground-breaking innovation challenging well-established paradigms of development and humanitarian intervention. Taken seriously, it implies sustained dialogue with all local stakeholders, absolute mutual respect and equality and consensus-based agreement and it potentially fulfils criteria for justice as mutual recognition. Alternatively, it is simply a heuristic device designed to co-opt local actors and provide a veneer of legitimacy to essentially selfinterested action - virtually a form of moderated domination.

Based on the strategic documents alone, one can conclude that the EU's strategic vision of the world and of itself has evolved over time, and currently contains elements of all three conceptualisations of justice. The Global Strategy is characterised by a stronger emphasis on ensuring the resilience of the EU itself, as well as a stronger role of the EU in the world. While it does not disregard the importance of international institutions, the prevalence of focus on effective multilateralism compared to the previous two document has visibly diminished. At the same time, the Global Strategy puts greater emphasis on mutual recognition, but not necessarily out of normative ambition, but more for pragmatic reasons. Assessing whether the EU can be considered a just foreign policy actor based on its strategic vision within this conceptual framework is necessary but insufficient. The missing component and the next phase of assessment of the EU's contribution to global justice requires an investigation of the EU's foreign policy actions and the implementation of its strategy in practice. 


\section{References}

Aggestam, L. (2008) ‘Introduction: Ethical Power Europe?’, International Affairs, 84(1): 1-11.

Andersson, J. J., Brattberg, E., Häggqvist, M., Ojanen, H., and Rhinard, M. (2011) 'The European Security Strategy: Reinvigorate, Revise or Reinvent?', Occasional UIpapers, 7/2011, Stockholm: Swedish Institute of International Affairs.

Barry, B. A. (1989) Treatise on Social Justice: Theories of Justice, (Vol. 1), London: Harvester-Wheatsheaf.

Biscop, S. (2004) The European Security Strategy: Implementing a Distinctive Approach to Security, Brussels: Royal Defence College.

Biscop, S., Howorth, J., and Giegerich, B. (2009) 'Europe: A Time for Strategy', Egmont Paper, 27.

Buchanan, A. (2004) Justice, Legitimacy, and Self-Determination: Moral Foundations for International Law, Oxford: Oxford University Press.

Bull, H. (1982) 'Civilian Power Europe: A Contradiction in Terms', Journal of Common Market Studies, 21(2): 149-170.

Caney, S. (2005) Justice Beyond Borders: A Global Political Theory, Oxford: Oxford University Press.

Document on the European Identity Published by the Nine Foreign Ministers [Copenhagen Declaration on European Identity] (1988) European Political Cooperation ( $5^{\text {th }}$ ed.), Copenhagen, 14 December.

Dryzek, J. S. (2013) 'The Deliberative Democrat's Idea of Justice', European Journal of Political Theory, 12(4): 329-346.

Dryzek, J. S. (2015) 'Democratic Agents of Justice', The Journal of Political Philosophy, 23(4): 361-384.

Duchêne, F. (1973) 'The European Community and the Uncertainties of Interdependence', in M. Kohnstamm and W. Hager (eds) A Nation Writ Large? Foreign-Policy Problems Before the European Community, London: Palgrave Macmillan.

Dworkin, R. (2011) Justice for Hedgehogs, Cambridge: Harvard University Press.

Eriksen, E. O. (2016) 'Three Conceptions of Global Political Justice', GLOBUS Research Paper, 1/2016, Oslo: ARENA Centre for European Studies.

European Council (2003) 'A Secure Europe in a Better World. European Security Strategy', available at http://www.consilium.europa.eu/media/30823/qc78095 68enc.pdf [accessed on 13 February 2018].

European Council (2007) Presidency Conclusions, D/07/6, Brussels, 14 December.

European Council (2008) 'Report on the Implementation of the European Security Strategy - Providing Security in a Changing World', available at https://www.consilium.europa.eu/uedocs/cms data/docs/pressdata/en/reports/1 04630.pdf [accessed 13 February 2018]. 
European Council (2015) 'Conclusions', European Council meeting, EUCO 22/5, 25 and 26 June, Brussels, available at https://europa.eu/globalstrategy/en/europeancouncil-conclusions-june-2015 [accessed on 13 February 2018].

European External Action Service [EEAS] (2016) 'Shared Vision, Common Action: A Stronger Europe. A Global Strategy for the European Union's Foreign And Security Policy', available at https://eeas.europa.eu/archives/docs/top stories/pdf/eugs review web.pdf [accessed on 13 February 2018].

Forst, R. (2012) The Right to Justification: Elements of a Constructivist Theory of Justice, New York: Columbia University Press.

Forst, R. (2015) 'Transnational Justice and Non-Domination', in B. Buckinx, J. TrejoMathys, and T. Waligore (eds) Domination and Global Political Justice, London: Routledge.

Fraser, N. (2007) 'Re-framing Justice in a Globalizing World', in T. Lovell (ed.) (Mis)recognition, Social Inequality and Social Justice, London: Routledge.

Gauthier, D. P. (1986) Morals by Agreement, Oxford: Clarendon Press.

Hebel, K. and Lenz, T. (2016) 'The Identity/Policy Nexus in European Foreign Policy', Journal of European Public Policy, 23(4): 473-491.

Kagan, R. (2003) Of Paradise and Power, New York: Alfred A. Knopf.

Kolers, A. (2014) 'The Priority of Solidarity to Justice', Journal of Applied Philosophy, 31(4): 420-433

Lovett, F. (2009) 'Domination and Distributive Justice', The Journal of Politics, 71(3): 817-830.

Lucarelli, S., and Manners, I. (2006) (eds) Values and Principles in European Union Foreign Policy, London: Routledge.

Manners, I. (2002) 'Normative Power Europe: A Contradiction in Terms?', Journal of Common Market Studies, 40(4): 235-258.

Mayer, H. and Vogt, H. (2006) A Responsible Europe? Ethical Foundations of EU External Affairs, Basingstoke: Palgrave MacMillan.

McCormick, J. (2006). The European Superpower, Basingstoke: Palgrave Macmillan

Merlini, C. (2001) 'Book Reviews and Notes', The International Spectator, 36(3): 111114.

Moellendorf, D. (2002) Cosmopolitan Justice, Boulder: Westview Press.

Moravcsik, A. (2009) 'Europe: The Quiet Superpower. French Politics, 7(3-4): 403-422.

Nagel, T. (2005) 'The Problem of Global Justice', Philosophy and Public Affairs, 33(2): $113-147$.

Official Journal of the European Communities (2002) Consolidated Version of the Treaty on the European Union and the Treaty Establishing the European Community, C 325/5, available at http://eur-lex.europa.eu/legal-content/EN/TXT/ ?uri=CELEX\%3A12002E\%2FTXT [accessed on 22 February 2018]. 
Official Journal of the European Union (2007) Treaty of Lisbon. Amending the Treaty on European Union and the Treaty Establishing the European Community, C 306/1, available at http://www.refworld.org/docid/476258d32.html [accessed on 22 February 2018].

Padoa-Schioppa, T. (2001) Europa, Forza Gentile, Bologna: il Mulino.

Pettit, P. (2010) 'A Republican Law of Peoples', European Journal of Political Theory, 9(1): 70-94.

Rawls, J. (1971) A Theory of Justice, Oxford: Oxford University Press.

Report by the Foreign Minister of the Member States on the Problems of Political Unification [Davignon Report] (1970), adopted by the Foreign Ministers, Luxembourg, 2017 October, Bulletin of the European Communities, 11(1970): 9-14.

Rynning, S. (2003) T'he European Union: Towards a Strategic Culture?', Security Dialogue, 34(4): 479-496.

Sen, A. (2009) The Idea of Justice, London: Allen Lane.

Singer, P. (2002) One World, the Ethics of Globalization, New Haven: Yale University Press.

Single European Act (1986) Bulletin of the European Communities, Supplement 2/86.

Sjursen, H. (2015) 'Normative Theory: An Untapped Resource', in K. E. Jørgensen, Å. K. Aarstad, E. Drieskens, K. Laatikainen and B. Tonra (eds) The SAGE Handbook of European Foreign Policy (vol 1), London: SAGE Publications.

Tocci, N. (2016) 'The Making of the EU Global Strategy', Contemporary Security Policy, 37(3): 461-472.

Toje, A. (2005) 'The 2003 European Union Security Strategy: A Critical Appraisal', European Foreign Affairs Review, 10(1): 117-133.

Walzer, M. (1983) Spheres of Justice: A Defense of Pluralism and Equality, New York: Basic Books.

Whitney, C. R. (1991) 'War in the Gulf: Europe; Gulf Fighting Shatters Europeans' Fragile Unity', New York Times, 25 January.

Wood, S. (2011) 'Pragmatic Power EUrope?', Cooperation and Conflict, 46(2): 242-261.

Young, I. M. (1990) Justice and the Politics of Difference, Princeton: Princeton University Press. 


\section{GLOBUS Research Papers}

$2 / 2018$

Nikola Tomić and Ben Tonra

The Pursuit of Justice Through EU

Security Strategies

Sisyphus Redux?

$1 / 2018$

Alexa Zellentin

Different Angles on Climate Justice Insights from Non-domination and Mutual Recognition

\section{$6 / 2017$}

Mai'a K. Davis Cross

Europe's Foreign Policy and the Nature of Secrecy

\section{$5 / 2017$}

Bettina Ahrens

The Solidarisation of International

Society:

The EU in the Global Climate Change Regime

\section{4/2017}

Mai'a K. Davis Cross

EU Institutions and the Drive for Peace

The Power of Ideas
$3 / 2017$

Kjartan Koch Mikalsen

Equal Sovereignty

On the Conditions of Global Political Justice

2/2017

Helene Sjursen

Global Justice and Foreign Policy

The Case of the European Union

$1 / 2017$

Franziskus von Lucke

O Justice, Where Art Thou?

Developing a New Take on Climate Justice

$1 / 2016$

Erik O. Eriksen

Three Conceptions of Global Political Justice 


\section{GLOBUS Research Papers}

The GLOBUS Research Papers are pre-print manuscripts on the EU's contribution to global justice as well as the wider question of Global Political Justice. The series is multidisciplinary, with a particular emphasis on the fields of international relations, political science, political theory, sociology and law.

\section{Reconsidering European Contributions to Global Justice - GLOBUS}

GLOBUS is a research project that critically examines the European Union's contribution to global justice. Challenges to global justice are multifaceted and what is just is contested. Combining normative and empirical research GLOBUS explores underlying political and structural obstacles to justice. Analyses of the EU's positions and policies are combined with in-depth studies of non-European perspectives on the practices of the EU. Particular attention is paid to the fields of migration, trade and development, cooperation and conflict, as well as climate change. GLOBUS' team of researchers covers the disciplines of politics, international relations, law, economics, sociology and political theory. The project is coordinated by ARENA Centre for European Studies at the University of Oslo and has partners in Brazil, China, Germany, India, Ireland, Italy and South Africa. It is funded by the Horizon 2020 Programme of the European Union for the period 1.6.2016 - 31.5.2020.

Series Editor

Helene Sjursen, ARENA Centre for European Studies, University of Oslo GLOBUS Coordinator.

\section{Editorial Board}

Thomas Diez

Erik O. Eriksen

Sonia Lucarelli Pundy Pillay

Ben Tonra
Institute of Political Science, University of Tübingen ARENA Centre for European Studies, University of Oslo Department of Political and Social Sciences, University of Bologna Wits School of Governance, University of Witwatersrand School of Politics and International Relations, University College Dublin 